\title{
Rare case of orbital schwannoma with intralesional haemorrhage and fluid-fluid levels
}

\author{
Bryan James Kantner, ${ }^{1}$ Brian Boldt ${ }^{1,2}$
}

'Department of Radiology, Madigan Army Medical Center, Tacoma, Washington, USA ${ }^{2}$ Uniformed Services University of the Health Sciences, Bethesda, Maryland, USA

\section{Correspondence to} Dr Bryan James Kantner, bjkantner@gmail.com

Accepted 19 June 2017

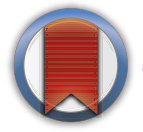

CrossMark

To cite: Kantner BJ, Boldt B. BMJ Case Rep Published Online First: [please include Day Month Year] doi:10.1136/bcr-2017-

219813

\section{DESCRIPTION}

We report a case of a 23-year-old man who presented with a 1-month history of gradually worsening right eye pressure, blurry vision and proptosis, which was not exacerbated with Valsalva or change in position.

MRI of the orbits demonstrated a well-defined, lobulated, cystic, trans-spatial mass with areas of internal haemorrhage (figure 1) and fluid-fluid levels (figure 2) in the superior medial right orbit, which extended posteriorly through the superior orbital fissure to the cavernous sinus (figure 3 ). The

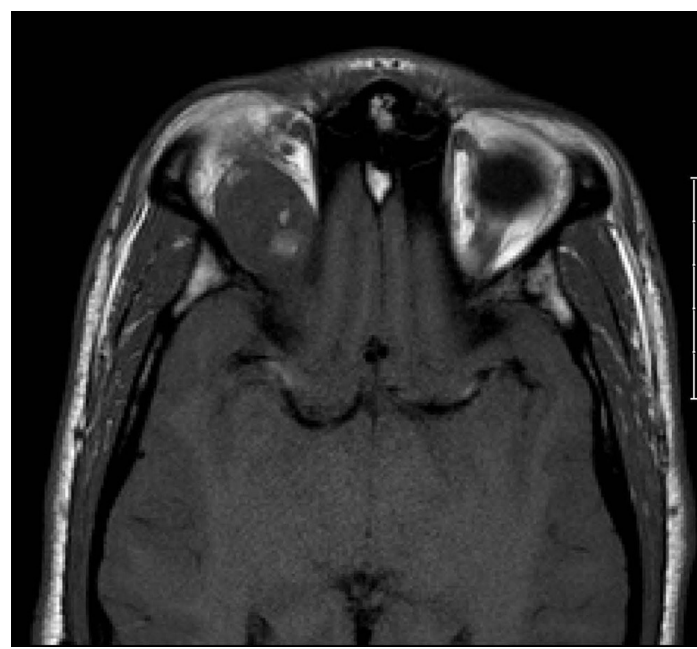

Figure 1 Axial T1: increased T1 signal within the lesion located in the right periorbital space indicating haemorrhage.

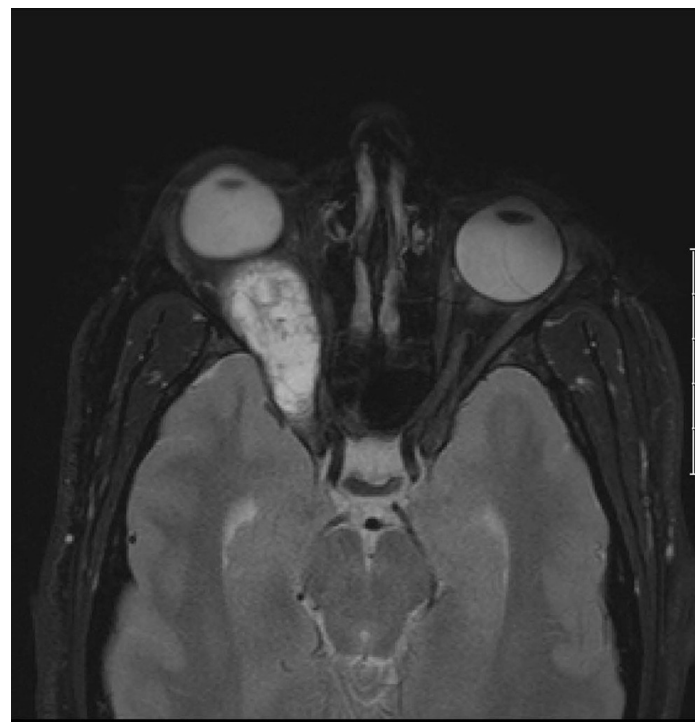

Figure 2 Axial T2 (superior): multiple fluid-fluid levels.

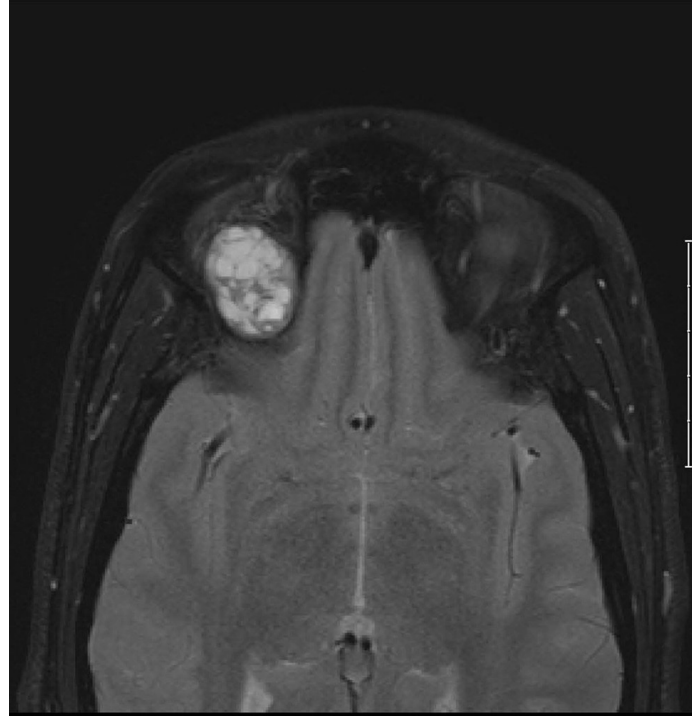

Figure 3 Axial T2 (inferior): lesion extending through the superior orbital fissure to the cavernous sinus.

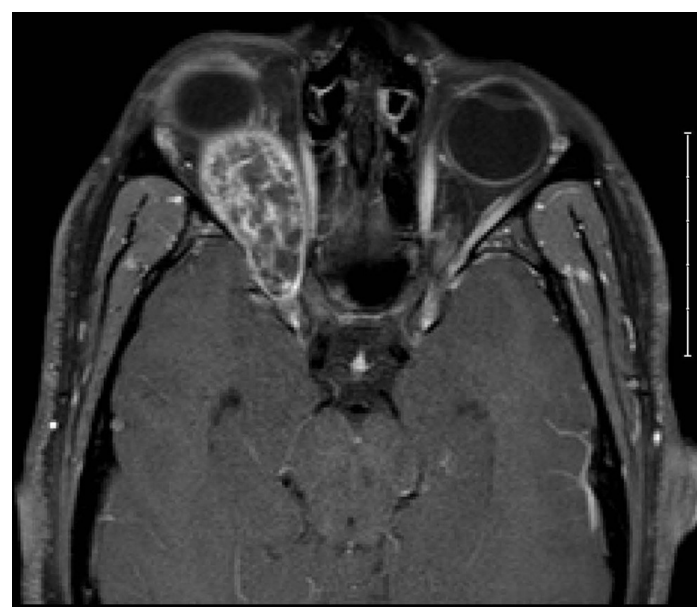

Figure 4 Axial T1 postcontrast: peripheral and septal enhancement.

lesion slightly expanded the orbital fissure, mildly deformed the posterior globe and demonstrated peripheral and septal enhancement (figure 4).

The differential considerations for these imaging findings include venolymphatic malformation, orbital varix and orbital schwannoma. The patient's clinical presentation and MRI findings of mass effect resulting in expansion of the orbital fissure are not typical for orbital varix, and the diagnoses of venolymphatic malformation versus schwannoma were considered. 
The patient subsequently underwent right frontotemporal craniotomy and surgical excision of a schwannoma arising from V1. The postoperative course was uncomplicated.

Schwannomas are rare in the orbit, accounting for 1\% of all orbital tumours. ${ }^{1}$ They are encapsulated, slowly progressive neoplasms most commonly located in the superior or medial superior aspect of the orbit, arising from branches of the trigeminal nerve. ${ }^{2}$ They have a diverse imaging appearance secondary

\section{Learning points}

- Schwannomas are rare in the orbit, accounting for $1 \%$ of all orbital tumours.

- Schwannomas are encapsulated, slowly progressive neoplasms most commonly located in the superior or medial superior aspect of the orbit, arising from branches of the trigeminal nerve.

- Schwannomas have a diverse imaging appearance, ranging from solid, cystic and solid, or predominately cystic tumours with regions of intralesional haemorrhage. to their mixed histological composition of cellular Antoni A tissue or hypocellular Antoni B tissue. This can produce solid, cystic and solid, or predominately cystic tumours with regions of intralesional haemorrhage and fluid-fluid levels. ${ }^{3}$

Contributors BJK: Interpreting resident on the neuroradiology service, primary article author, conducted review of literature, image acquisition and pathological correlation. BB: Interpreting faculty neuroradiologist on the neuroradiology service, staff advisor for article submission, conducted review and contributed revisions to article draft before submission, conducted additional review of literature.

Competing interests None declared.

Patient consent Obtained.

Provenance and peer review Not commissioned; externally peer reviewed.

(C) BMJ Publishing Group Ltd (unless otherwise stated in the text of the article) 2017. All rights reserved. No commercial use is permitted unless otherwise expressly granted.

\section{REFERENCES}

1 Wang Y, Xiao LH. Orbital schwannomas: findings from magnetic resonance imaging in 62 cases. Eye 2008;22:1034-9.

2 Tailor TD, Gupta D, Dalley RW, et al. Orbital neoplasms in adults: clinical, radiologic, and pathologic review. Radiographics 2013;33:1739-58.

3 Gündüz K, Kurt RA, Erden E. Orbital schwannoma with fluid-fluid levels on MRI. Ophthal Plast Reconstr Surg 2011;27:51-3.

Copyright 2017 BMJ Publishing Group. All rights reserved. For permission to reuse any of this content visit

http://group.bmj.com/group/rights-licensing/permissions.

BMJ Case Report Fellows may re-use this article for personal use and teaching without any further permission.

Become a Fellow of BMJ Case Reports today and you can:

- Submit as many cases as you like

- Enjoy fast sympathetic peer review and rapid publication of accepted articles

- Access all the published articles

- Re-use any of the published material for personal use and teaching without further permission

For information on Institutional Fellowships contact consortiasales@bmjgroup.com

Visit casereports.bmj.com for more articles like this and to become a Fellow 